\title{
Survey for the Incidence of Viral Diseases in Chilli in Andhra Pradesh, India
}

\author{
D. Bhagavathi Devi*, M. Krishna Reddy, B. Padmodaya, V.L.N. Reddy and V. Srilatha
}

Department of Plant Pathology, S.V. Agriculture College, Tirupati, India

*Corresponding author

\begin{tabular}{l} 
Key w or d s \\
$\begin{array}{l}\text { Capsicum annuum, } \\
\text { Chili production, } \\
\text { Mosaic, Ring spot, } \\
\text { Curling, Yellowing }\end{array}$ \\
Article Info \\
$\begin{array}{l}\text { Accepted: } \\
17 \text { October } 2019 \\
\text { Available Online: } \\
10 \text { November } 2019\end{array}$ \\
\hline
\end{tabular}

\section{A B S T R A C T}

Chili (Capsicum annuum L.) is an economically important and widely cultivated crop of India. Viral diseases in Chilli is one of the major limiting factors in chili production, which decreases yield significantly. The experiment was carried out in during 2016-18 in different districts of Andhra Pradesh randomly. Maximum disease incidence of 45.05 per cent was recorded from Narpali mandal of Anantapur District and minimum incidence of 6.66 per cent was recorded in N.G Padu village of Prakasam. The district wise average incidence was assessed in the field with visual assessment and it revealed the maximum incidence was observed in Anantapur (45.05\%) followed by kadapa (25.55\%), Kurnool (17.99\%), Guntur (14.15\%) Prakasam (11.24\%) and with minimum incidence in Krishna (7.16\%).

\section{Introduction}

Chilli (Capsicum annuum L) is one of the most valuable cash crops of India. It is a common and widely cultivated spices crop almost all over the world. Chilli is a richest source of vitamin $\mathrm{C}$ and $\mathrm{A}$ (Howard and Talcott et al., 2000).

The chilly fruits are small in size and known for their sharp acidic flavor and colour. At present, chilly is produced in India about 1260.1thousands metric ton from an area of 792.1 thousand hectare, Anonymous (2012).
Andhra Pradesh is the largest producing state of chilly. Indian chillies are mostly exported to Sri Lanka, USA, Nepal, Mexico, Malaysia and Bangladesh.

Chilli suffers from a large number of viral, fungal, bacterial, nematode and phytoplasma diseases.

Viruses is known to cause different symptoms like mosaic, ring spot, curling, yellowing etc. on chilly and these symptoms result heavy economic losses of about 15billion US Dollar per annum worldwide Van Fanbing (1999). 


\section{Materials and Methods}

\section{Survey}

Roving survey was conducted during 2016-18 in different districts of Andhra Pradesh to assess the status of viruses infecting chilli. A minimum of five fields were selected randomly in each location for assessing the disease status. Incidence of the disease, variability of symptoms and crop variety, were recorded.

The per cent disease incidence was calculated using the following formula

Per cent disease incidence

Total number of infected plants

= -

Total number of plants observed

\section{Results and Discussion}

Rovging survey will be conducted from August 2016 to June 2018 in major chilli growing regions of Andhra Pradesh state to assess the incidence of viruses infecting chilli. The field survey was conducted by random selection of rows of plants grown in the field for estimating disease incidence. In each field, five plots of $10 \mathrm{~m} 2$ were selected and the percentage of disease was calculated after counting the total number of plants in selected plot area and the number of diseased plants showing varying degrees of leaf curl symptoms separately.

The surveyed data is presented in (Table 1) revealed that viral diseases were present in almost all parts of the six districts that were surveyed. Disease incidence ranged from a minimum of 7.16 per cent to complete failure of crop. Maximum disease incidence of 45.05 per cent was recorded from Narpali mandal of Anantapur District and minimum incidence of
6.66 per cent was recorded in N.G padu village of Prakasam. The district wise average incidence was assessed in the field with visual assessment and it revealed the maximum incidence was observed in Anantapur $(45.05 \%)$ followed by kadapa (25.55\%), Kurnool (17.99\%), Guntur (14.15\%) Prakasam (11.24\%) and with minimum incidence in Krishna (7.16\%).

In the field conditions, majority of the plants showed severe leaf curling in both upward and downward directions with puckering, crinkling of leaves and in many cases with petiole elongation and complete sterility (Plate 1f and g). Reduced leaf size, leaf distortion, stunting and blistering, defoliation and fewer and smaller fruits were the other characteristic symptoms observed. In case of virus inducing symptoms, dark green mottle and vein banding were noticed in most cases (Plate 1a). Chlorotic and necrotic spots and rings on leaves and apical necrosis, which are characteristic symptoms of Tospoviruses were also observed in very few plants (Plate 1e and h). During survey, major symptoms observed was severe leaf curling, stunting and complete sterility of the plants. Upward curling, puckering and internal eruptions of leaves produced by thrips as reported by Reddy and Puttaswamy (1983) was noticed along with mite causing symptoms on chilli viz., downward curling, crinkling of leaves and elongation of leaf petiole.

Thrips which produces eruption of internal areas and puckering of leaves, upward curling of leaves (Plate if and g) and mites which produces downward curling, crinkling of leaves and elongation of leaf petiole followed by blister patches (Plate 1c and d) were more commonly observed in all fields visited and their population was more in rainfed chilli crop. It was noticed that majority of the farmers had already taken appropriate control measures (Fig. 1). 
Table.1 Survey for the incidence of viruses infecting chilli in Andhra Pradesh

\begin{tabular}{|c|c|c|c|c|c|c|c|c|}
\hline $\begin{array}{l}\text { S } \\
1 . \\
\text { N } \\
\text { o. }\end{array}$ & districts & $\begin{array}{l}\text { Name of the } \\
\text { mandal }\end{array}$ & $\begin{array}{l}\text { Name of the } \\
\text { location }\end{array}$ & Variety/line & $\begin{array}{l}\text { Mosaic } \\
\text { PDI }\end{array}$ & $\begin{array}{c}\text { Tospo } \\
\text { PDI }\end{array}$ & $\begin{array}{l}\text { Leafcurl } \\
\text { PDI }\end{array}$ & PDI mean \\
\hline \multirow[t]{15}{*}{1.} & Guntur & Gunture & LAM & Ramya Teja & 1.5 & 12 & 30 & 14.5 \\
\hline & & Chebrole & vengalayapalya & U.S.A341 & 2.0 & 20 & 40 & 20.66 \\
\hline & & amaravathi & jupudi & Ramya Teja & 1.5 & 1.5 & 50 & 17.66 \\
\hline & & & amaravathi & $\begin{array}{c}\text { Ramya Teja, } \\
\text { Lca-334 }\end{array}$ & 2.0 & 1.5 & 40 & 14.50 \\
\hline & & Rajupalem & ganapavaram & $\begin{array}{c}\text { Ramya Teja, } \\
\text { Lca-334 }\end{array}$ & 5.0 & 10 & 50 & 21.66 \\
\hline & & pedakurapadu & pedakurapadu & $\begin{array}{c}\text { Ramya Teja, } \\
\text { Lca-334 }\end{array}$ & 1.5 & 2.5 & 60 & 21.33 \\
\hline & & muppalla & muppalla & Lca-334, teja & 1.5 & 2.0 & 50 & 17.83 \\
\hline & & prattipadu & prattipadu & $\begin{array}{c}\text { Lca-334 } \\
\text { vinjanampadu. }\end{array}$ & 1.0 & 5 & 20 & 8.66 \\
\hline & & tadikonda & tadikonda & Indam-5 & 2.0 & 5 & 30 & 12.33 \\
\hline & & Veldurthi & Veldurthi & Indam5,334 & 2.0 & 0 & 20 & 7.33 \\
\hline & & machavaram & machavaram & $\begin{array}{l}\text { Lca-334, } \\
\text { vinjanampadu }\end{array}$ & 3.0 & 21 & 35 & 19.66 \\
\hline & & Tenali & Tenali & Teja 273 & 1.5 & 3 & 30 & 11.50 \\
\hline & & pedakurapadu & & Indam-5 & 2.0 & 11 & 20 & 11.00 \\
\hline & & sattinapalli & & Lca-334 & 1.5 & 10 & 20 & 10.50 \\
\hline & & & & & & & Mean & 14.15 \\
\hline \multirow[t]{5}{*}{2.} & kurnool & nandyala & nandyala & Teja 273 & 0 & 1.5 & 50 & 17.167 \\
\hline & & Gadivemula & giddalluru & & 0 & 2.0 & 70 & 24.000 \\
\hline & & panyam & panyam & Syngenta444 & 0 & 1.5 & 50 & 17.16 \\
\hline & & Nandikotkur & Nagatoor & & 0 & 1.0 & 40 & 13.66 \\
\hline & & & & & & & Mean & 17.99 \\
\hline \multirow[t]{8}{*}{3.} & Anantapur & Narpali & dhayalakota & & $1-1.5$ & 0.1 & 90 & 45.05 \\
\hline & & Guntakal & Nagasamudram & 273 Teja, byadgi & 10 & 1.5 & 80 & 30.500 \\
\hline & & Vajrakarur & konakonla & 273 Teja, byadgi & 0 & 1.5 & 89 & 30.167 \\
\hline & & uravakonda & muddalapuram & Gunture mirchi & 11 & 2 & 80 & 31.000 \\
\hline & & Kanekal & Udegolam & Syngenta 444 & 10 & 2 & 70 & 27.333 \\
\hline & & D.Hirehal & Lingamanahalli & 273 Teja, byadgi & 2 & 11 & 60 & 24.333 \\
\hline & & Hindupur & Maluguru & HINDPUR-S7 & 1.5 & 0 & 60 & 20.50 \\
\hline & & & & & & & Mean & 29.82 \\
\hline \multirow[t]{2}{*}{4.} & krishna & avanigadda & avanigadda & Local vareity & 0 & 1.5 & 20 & 7.167 \\
\hline & & & & & & & Mean & 7.16 \\
\hline
\end{tabular}


Int.J.Curr.Microbiol.App.Sci (2019) 8(11): 2136-2143

\begin{tabular}{|c|c|c|c|c|c|c|c|c|}
\hline 5. & prakasam & dornala & dornala & Lca-334,siri & 0 & 1.0 & 40 & 13.66 \\
\hline & & pullalacheruvu & pullalacheruvu & vinjanampadu & 0 & 3.0 & 40 & 14.33 \\
\hline & karamchedu & karamchedu & Lca-334 & 0 & 1.0 & 30 & 10.33 \\
\hline & & N.G padu & N.G padu & Lca-334 & 0 & 0 & 20 & 6.66 \\
\hline & & & & & & Mean & $\mathbf{1 1 . 2 4}$ \\
\hline 6 & Kadapa & Mydukur & $\begin{array}{c}\text { Kesalingaya } \\
\text { palle }\end{array}$ & & 2.0 & 0 & 70 & 24.0 \\
& & & Bhumayapalle & & 1.5 & 0 & 80 & 27.1 \\
\hline & & & & & & Mean & $\mathbf{2 5 . 5 5}$ \\
\hline
\end{tabular}

Plate.1 Variation of symptoms induced by viruses on Capsicum annuum L during survey

a) Green mottling and vein banding of ChiVMV

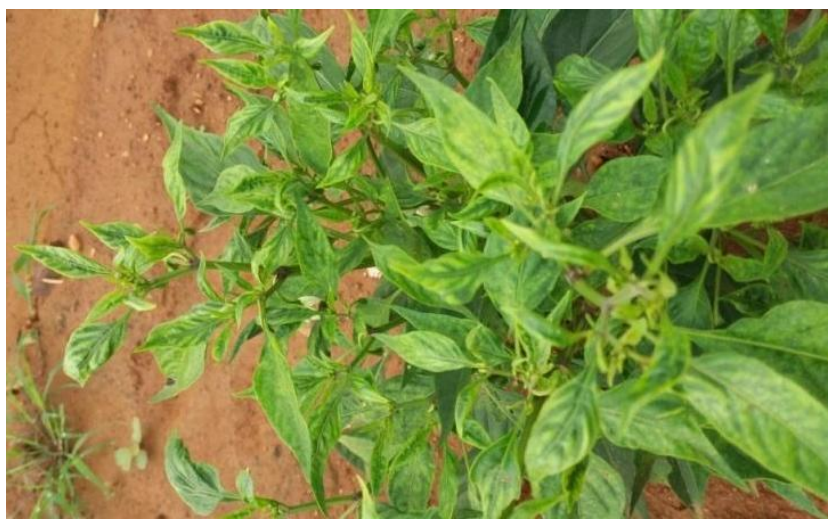

c) Mosaic symptoms on leaves of CMV

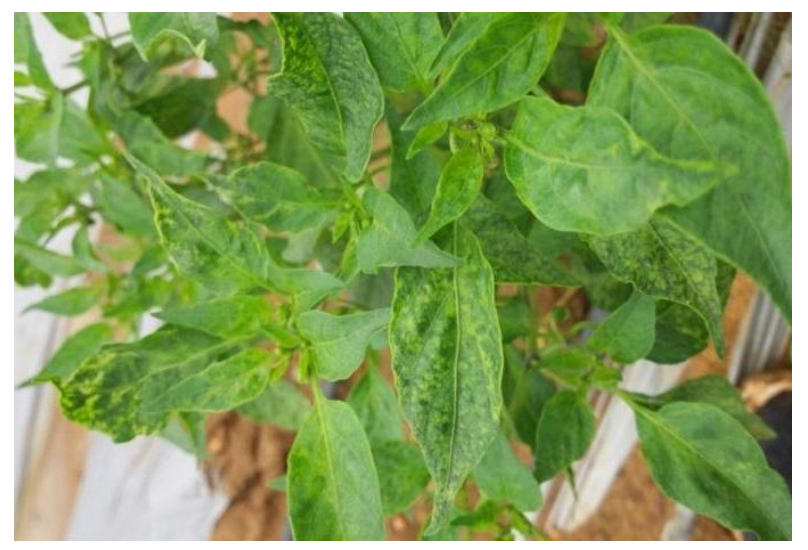

b) Stunting and leaf curling symptoms of ChLCV

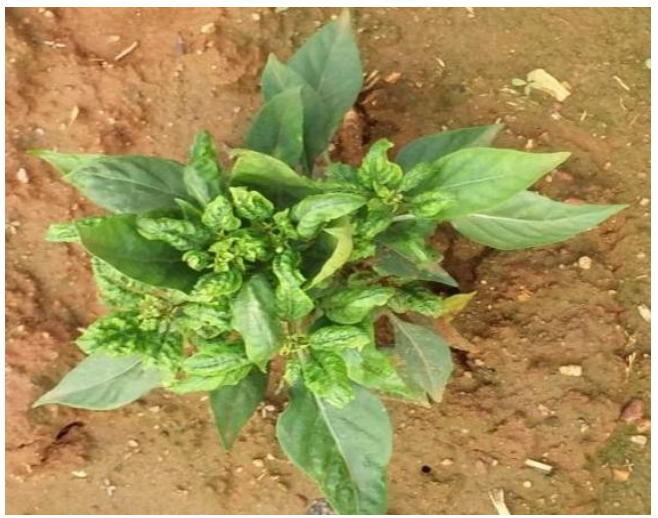

d) Leaf elongation and mosaic symptoms of CMV

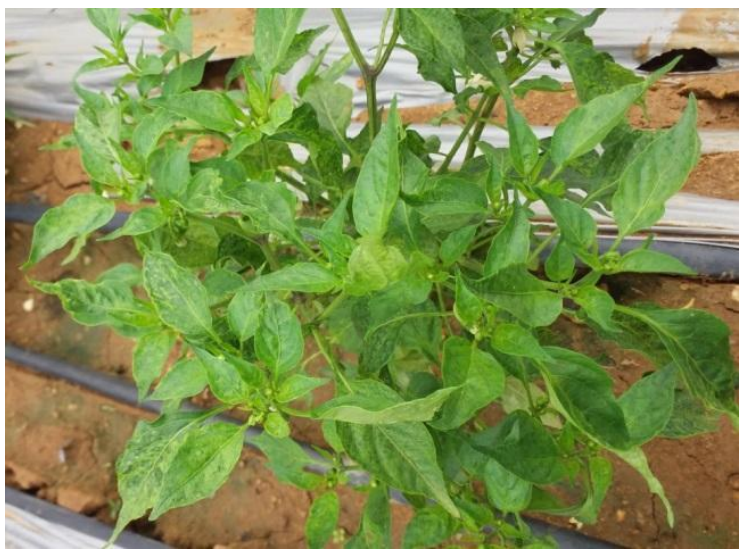


e) Necrotic rings symptoms of GBNV

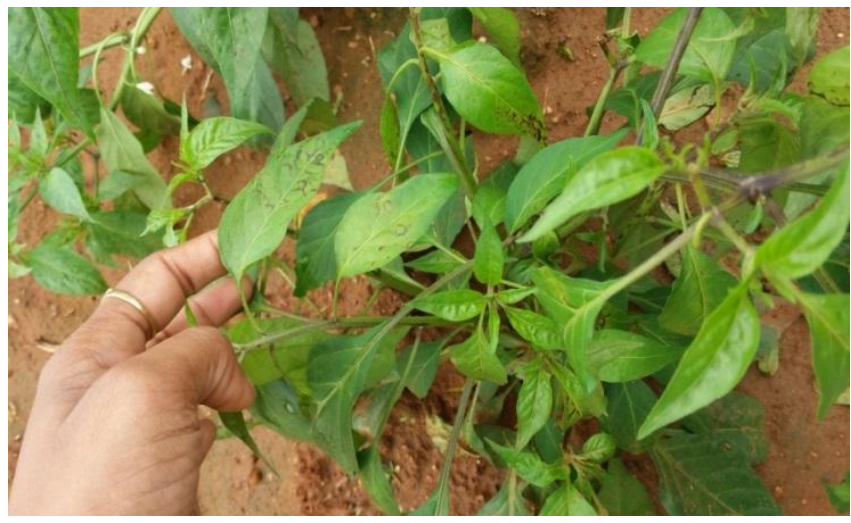

g) Upward curling of leaves of ChLCV
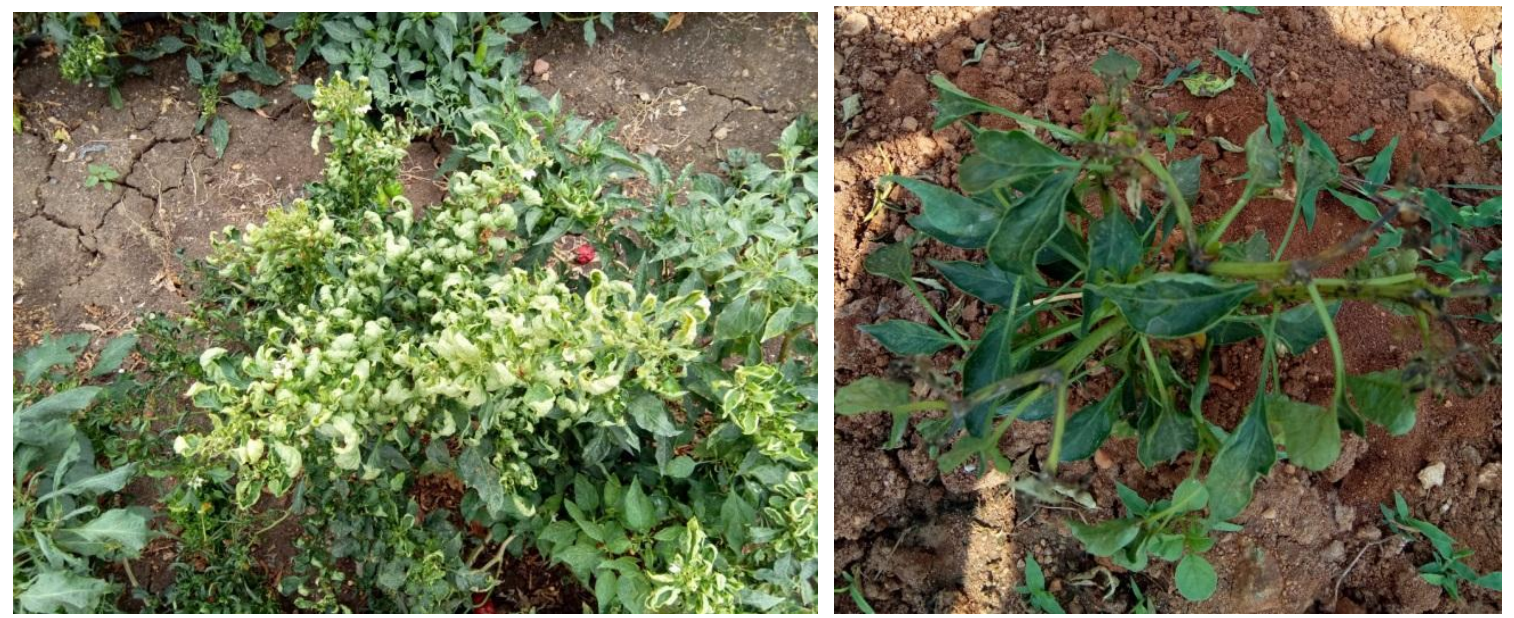

i) Mosaic, crinkling and shorting of fruit

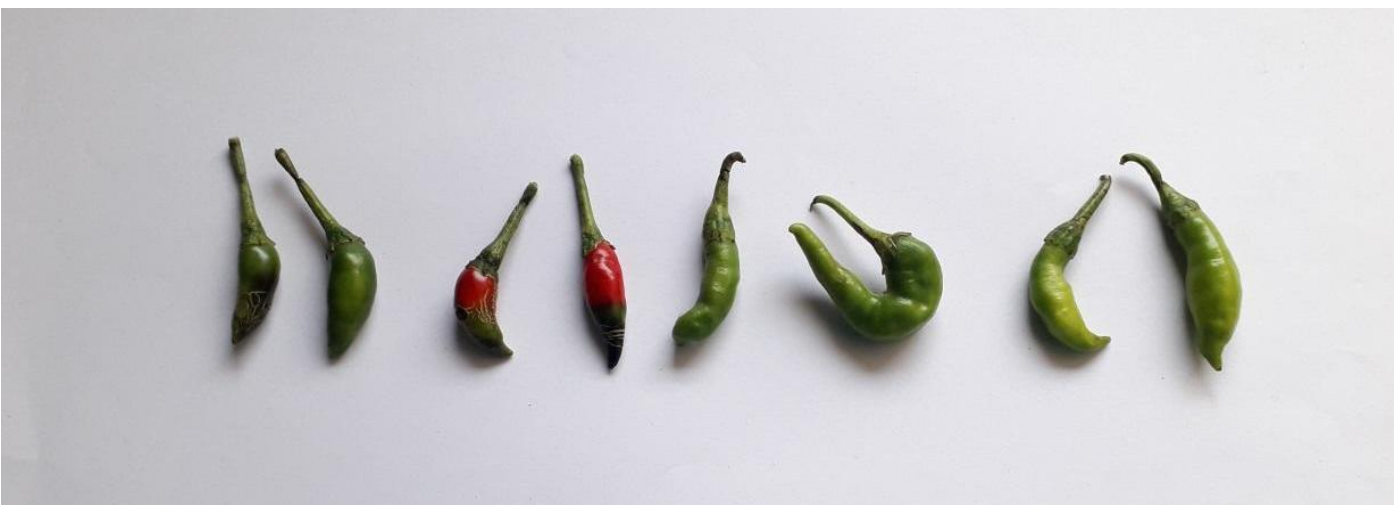




\section{j) Mosaic, Green mottling and vein banding of ChiVMV}

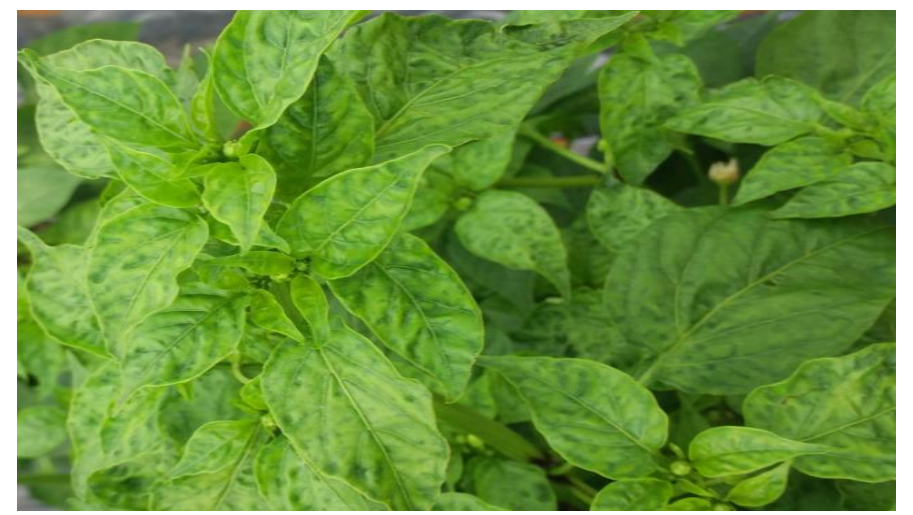

Fig.1 Survey for the incidence of viruses infecting chilli in Andhra Pradesh

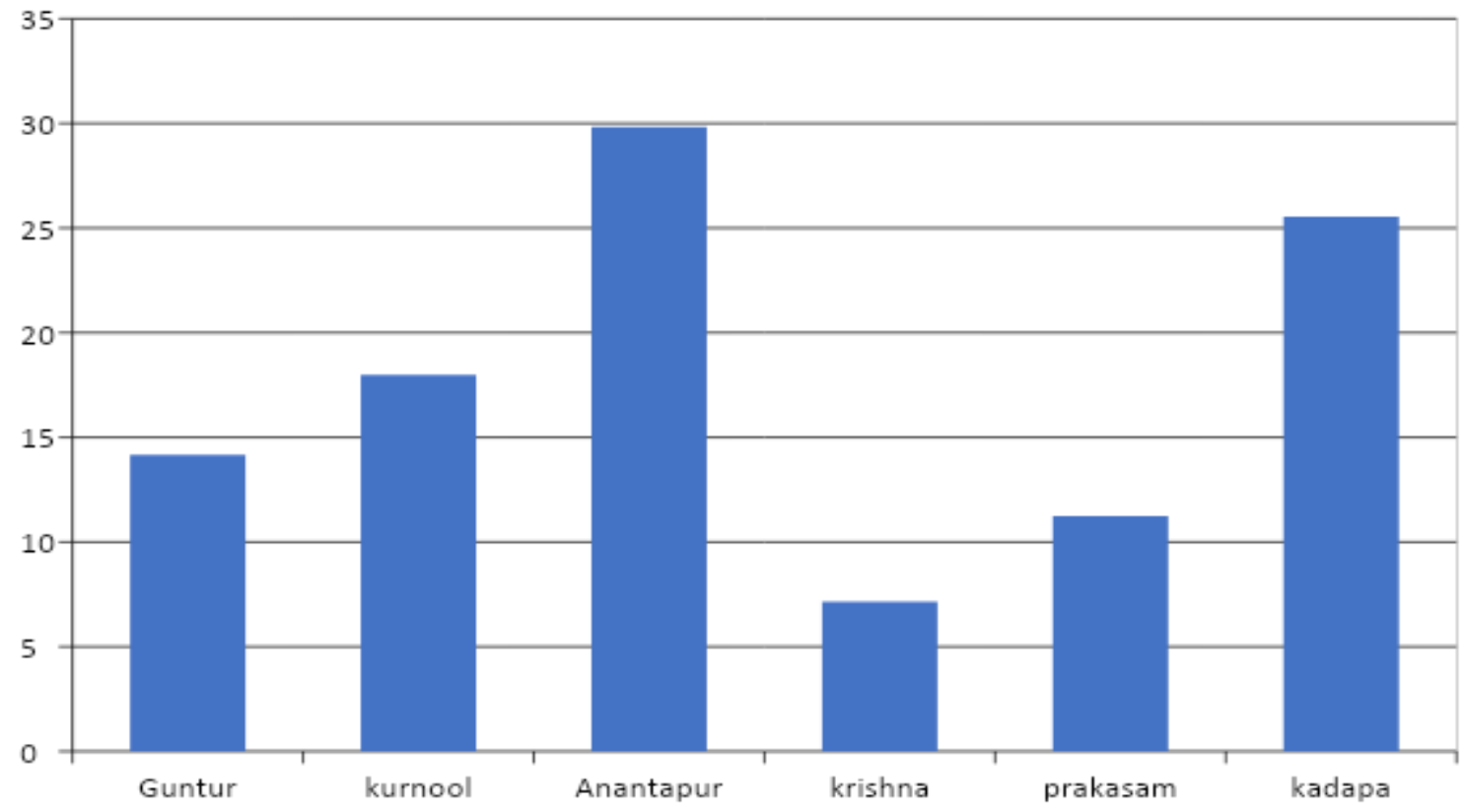

The symptoms on fruit (Plate 1, i) of infected plants varied from distortions to various types of colour deviations. Fruit distortions included surface roughness, twisting and malformation. The chilli fruits showed mottling of varying intensities. The fruits became reddish brown or dirty brown 1-2 days before ripening and disappeared totally when the fruits were fully red.

The disease symptoms observed on chilli plants were similar to the findings of Ong et al., (1979) who reported that vein mottling was more pronounced on bell type chilli than on hot types and also reported leaf distortions of ChiVMV infected plants.

Also, Sulaiman and Gim (1981) reported that leaves of ChiVMV and TMV infected plants exhibited varying degrees of vein clearing, mottling and chlorosis with i.e. mottling and swelling on stem. Variability in appearance of symptoms i.e., vein mottling, malformation, reduction in leaf areas were observed due to 
differences in cultivars, time of infection and climatic conditions as reported by Abu-Kasim (1986). Previously, similar field symptoms on have been reported by Fujisawa et al.,(1986) in Japan; Hameed et al., (1995) in Pakistan; Satya Prakash et al., (2002) in India and Cerkauskas et al., (2004) in Taiwan, Republic of China.

Chilli sucking pest's viz., thrips and mites which act as vectors for many viruses and also as associates of this complex disease were found in appreciable population in all most all fields.

Similar observations were made by Puttarudraiah (1959) who reported the involvement of thrips and mites as the cause of the murda complex in Karnataka. Surveys conducted by AVRDC in Asia identified aphids (Myzus persicae Sulzer, Aphis gossypi Glover), mite (Polyphagotarsonemus latus Banks) and thrips (Scirtothrips dorsalis Hood) as the major pests of chilli also supports the involvement of above pests' complex disease in chilli ((Berke and Sheih, 2000).

Hussain et al., (2008) reported Chilli veinal mottle virus (ChiVMV) as one of the prevalent chilli-infecting viruses found throughout chilli growing areas of Pakistan and observed 44.7 per cent relative occurrence of the virus in the country during 2003 and 2004. Therefore, majority of the viral symptoms associated with insect pest symptoms noticed in the survey revealed the ChiVMV existence and for its prevalence.

Individual plants occurring sporadically showing chlorotic, necrotic spots symptoms on leaves with typical apical necrosis were observed. Similar observations were made by Krishnareddy et al., (2008).

Individual plants showing severe leaf curl with typical cup-shaped, upward curling of leaves and yellowing and their association with sucking pest complex was not noticed in this study. Such symptoms are characteristic of begomoviruses in chilli as described by Chattopadhyay et al., (2008) and Shafiq et al., (2010).

An overall survey revealed that chilly leaf curl virus is more predominant viruses in all growing areas of chilli in Andhra Pradesh. It is due to growing of susceptible local cultivars prevailing in the districts as for multiplication and spread of virus.

\section{References}

Abu-Kassim. A.B. (1986). Vims diseases of horticultural crops in Malaysia. In: FFTC Book series. Food mid Fertilizer Teclmolog' Center for the Asian and Pacific Region. Taipei. Taiwan, p. 193.

Anonymous (2012) Area and production of vegetable crops, 2011-12. National Horticulture Board pp. 29.

Berke, T. and Sheih, S. C. (2000). Chilli peppers in Asia. Capsicum and Egg Plant Newsl, 19: 38-41.

Cerkauskas, C Kalb. T. and Chew. B. H. (2004). Chili veinal mottle virus: Apliid-Transmitted potyvirus. "'Pepper diseases". Asian Vegetable Research and Development Center, The World Vegetable Center. Fact Sheet. 04-589.

Chattopadhyay, B., Singh, A. K., Yadav, T., Fauquet, C. M., Sarin, N. B. and Chakraborty, S., 2008, Infectivity of the cloned components of a begomovirus: DNA beta complex causing chilli leaf curl disease in IndiaArch. Virol., 153(3): 533-539.

Fujisava, I., Hanada, T. And Saharan, A., 1986, Virus diseases occurring on some vegetable crops in West Malaysia. Japan. Agri. Res., 20:78-84.

Hameed, S., Shall. H. Ali. H. and viruses in Pakistan. Fifth 1995 March 28-30: 
NARC Khalid. S. (1995). Prevalence of chilli National Congress of Plant Sciences.. Islamabad.

Howard LR, Talcott ST, Brenes CH, Villalon B (2000) Changes on Phytochemical antioxidant activity of selected pepper cultivars (Capsicum Species) as influenced by maturity. Journal of Agricultural Food chemistry 48(5): 1713-1720.

Hussain S, Yasmin T, Fahim M, Hameed S, Haque MI. Transmission and host range studies of Pakistani isolate of Chilli veinal mottle virus. Pak. J Bot. 2008; 40(6): 2669-2681.

Krishnareddy, M., Usha Rani, R., Anil Kumar, K. S., Madhavi Reddy., K. and Pappu, H. R., 2008, Capsicum chlorosis virus (Genus Tospovirus) Infecting Chili Pepper (Capsicum annuum) in India. Plant Dis., 92: 1469.

Ong, C. A., Varghese, G. and Ting, W. P., 1979, Aetiological investigations on a veinal mottle virus of chilli (Capsicum aпnиит L.) newly recorded from peninsula Malaysia. Mardi Res Bull., 7: 78-88.
Puttarudraiah, M.,1959, Short review on the chilli leaf curl complex and the spray programme for its control. Mysore Agricultural Journal, 34:93-95.

Satya Prakash. Singh. S. J. Singh. R. K. and Upadhyayn. P. P. (2002) Distribution, incidence and detection of a Potyvirus on chilli from eastern Uttar Pradesh. Indian PhytopathoL, 55 (3): 294-298

Shafiq Muhammad, Shaheen Asad, Yusuf Zafar, Rob, W., Briddon and Shahid Mansoor, 2010, Pepper leaf curl Lahore virus requires the DNA B component of Tomato leaf curl New Delhi virus to cause leaf curl symptoms. Virology J., 7: 367

Sulaiman. I. and Gim. W. N. (1981). Sypmtomatology of Tobacco Mosaic Virus (TMV) and Chilli Veinal Mottle Virus (CVMV) on six local Chilli. Pertanika, 4(1): 10-15.

Van Fanbing L (1999) Monoclonal and recombinant antibodies of potyviral proteins and their application, Virology, Stuttgart University, Germany. 185: 151-161.

\section{How to cite this article:}

Bhagavathi devi, D., M. Krishna Reddy, B. Padmodaya, V. L. N. Reddy and Srilatha, V. 2019. Survey for the Incidence of Viral Diseases in Chilli in Andhra Pradesh, India. Int.J.Curr.Microbiol.App.Sci. 8(11): 2136-2143. doi: https://doi.org/10.20546/ijcmas.2019.811.248 